\title{
DISCHARGE AND WATER QUALITY OF HORSE CREEK, SOUTHEASTERN WYOMING, MAY-NOVEMBER, 1985
}

U.S. GEOLOGICAL SURVEY

Open-File Report 86-69

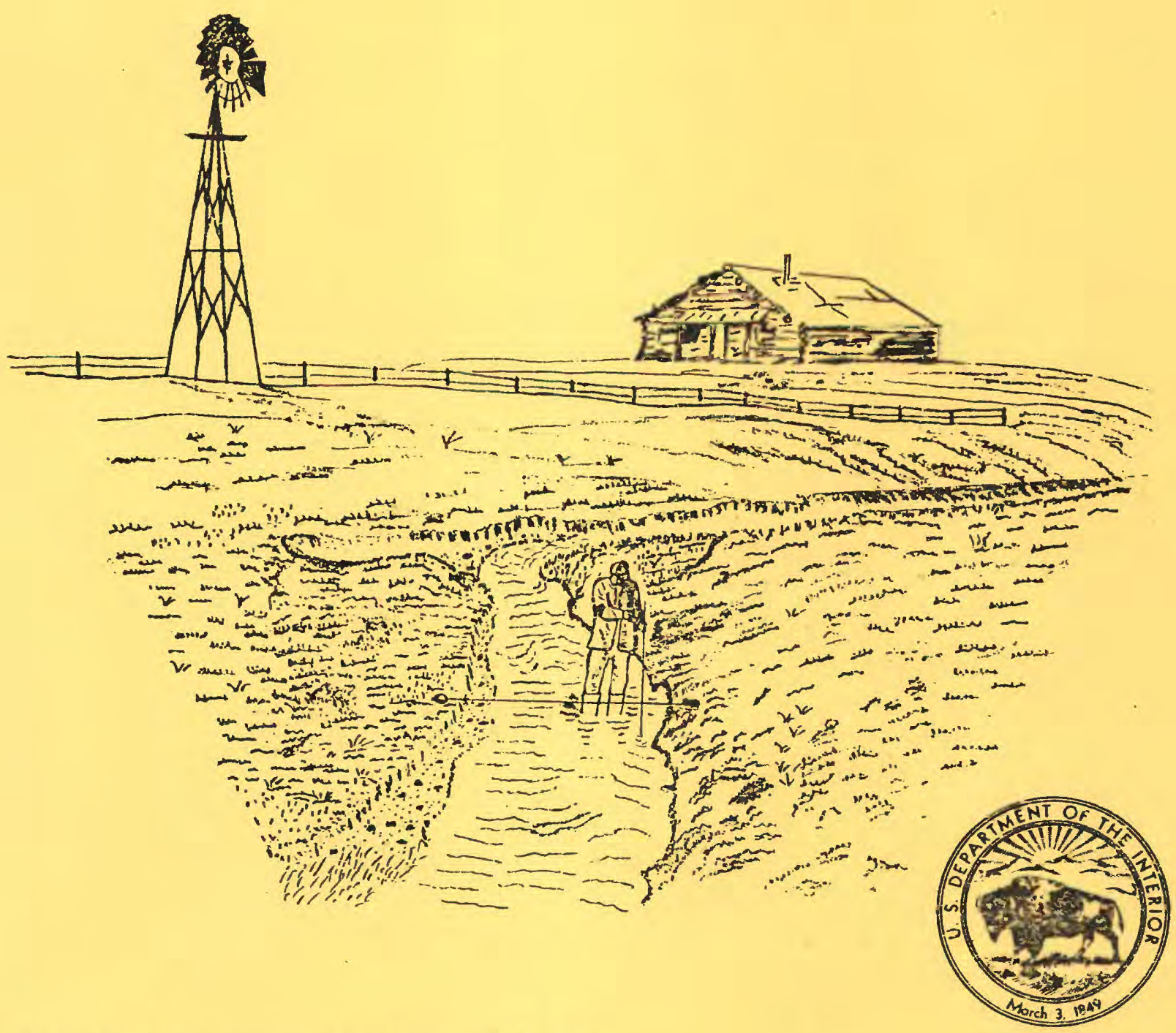

Prepared in cooperation with the WYOMING WATER DEVELOPMENT COMMISSION 
DISCHARGE AND WATER QUALITY OF HORSE CREEK, SOUTHEASTERN WYOMING, MAY - NOVEMBER, 1985

By J. F. Meyer and L. W. Lenfest, Jr.

U.S. GEOLOGICAL SURVEY

Open-File Report 86-69

Prepared in cooperation with the

WYOMING WATER DEVELOPMENT COMMISSION

Cheyenne, Wyoming

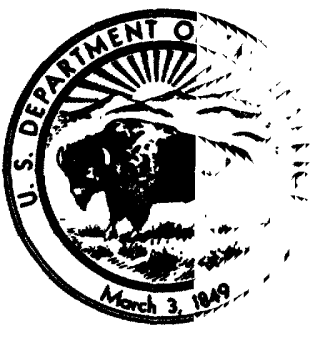


UNITED STATES DEPARTMENT OF THE INTERIOR

DONALD PAUL HODEL, Secretary

GEOLOGICAL SURVEY

Dallas L. Peck, Director

For additional information write to:

Copies of this report can be purchased from:

District Chief

U.S. Geological Survey

Open-File Services Section

2120 Capitol Avenue

P.0. Box 1125

Cheyenne, Wyoming 82003

Western Distribution Branch

U.S. Geological Survey

Box 25425, Federal Center

Denver, Colorado 80225

(Telephone: (303) 236-7476) 
Abstract. ............................................

Introduction .......................................

Data collection. ......................................

References cited..

Figure 1. Map showing study reach of Horse Creek and location of stream-discharge and water-quality

measurement sites......................

2-6. Photographs showing:

2. Upstream view of Horse Creek at siphon near

Yoder, Wyoming, October 21, 1985..............

3. Downstream view of Dry Creek near

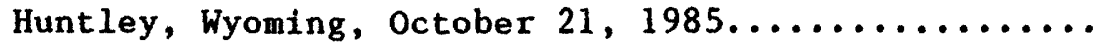

4. Upstream view of Horse Creek below Dry Creek near Huntley, Wyoming, October $21,1985 . \ldots \ldots \ldots \ldots$

5. Downstream vlew of Horse Creek above South Horse Creek lateral near Huntley, Wyoming,

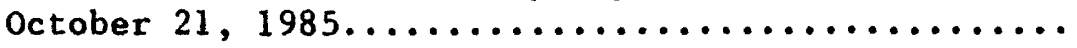

6. Downstream view of Horse Creek near Lyman,

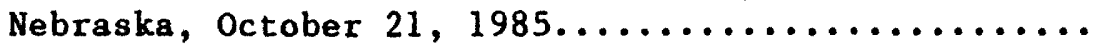

7-11. Graphs showing stream discharge, specific conductance, $\mathrm{pH}$, and water temperatures at:

7. Horse Creek at siphon near Yoder, Wyoming..........

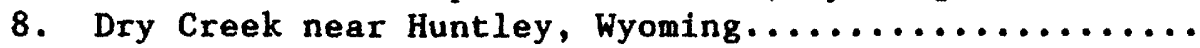

9. Horse Creek below Dry Creek near Huntley, Wyoming....

10. Horse Creek above South Horse Creek lateral near Huntley, Wyoming........................ 11

11. Horse Creek near Lyman, Nebraska................ 12

12. Graph showing stream-discharge gain or loss between measurement sites on Horse Creek.............

\section{TABLES}

Tables 1-5. Stream-discharge and water-quality measurements made during 1985 of:

1. Horse Creek at siphon near Yoder, Wyoming...........

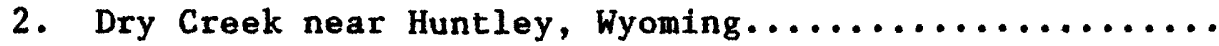

3. Horse Creek below Dry Creek near Huntley, Wyoming.....

4. Horse Creek above South Horse Creek lateral near

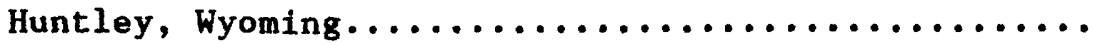

5. Horse Creek near Lyman, Nebraska................. 16

6. Stream-discharge changes for three stream reaches located 


\section{CONVERSION FACTORS}

For use of readers who prefer to use metric units, conversion factors for terms used in this report are listed below:

Multiply

mile

cubic foot per second
By

1.609

0.02832

\section{To obtain}

kilometer cubic meter per second

Temperature in degrees Celsius $\left({ }^{\circ} \mathrm{C}\right)$ can be converted to degrees Fahrenheit $\left({ }^{\circ} \mathrm{F}\right)$ as follows:

$$
{ }^{\circ} \mathrm{F}=9 / 5\left({ }^{\circ} \mathrm{C}\right)+32
$$


DISCHARGE AND WATER QUALITY OF HORSE CREEK, SOUTHEASTERN WYOMING, MAY - NOVEMBER, 1985

By J. F. Meyer and L. W. Lenfest, Jr.

\begin{abstract}
This report presents stream-discharge and water-quality data collected at five sites in the lower Horse Creek drainage of southeastern Wyoming, May through November, 1985. Data include streamdischarge measurements; field measurements of specific conductance, $\mathrm{pH}$, and water temperature; and computed changes in stream discharge. Measured discharge in Horse Creek ranged from 0.91 to 172 cubic feet per second. Values of $\mathrm{pH}$ averaged 8.4. Water temperature ranged from 0 to 27 degrees Celsius. The data are presented in graphs and tables. A map of the study reach shows the location of the data-collection sites.
\end{abstract}

\title{
INTRODUCTION
}

Stream-discharge and water-quality data were collected in the lower Horse Creek drainage basin in cooperation with the Wyoming Water Develcpment Commision. Data were collected to define stream-discharge and water-quality changes in Horse Creek, May through November, 1985.

The Horse Creek study reach (fig. 1) begins at site 1, just upstream of the Fort Laramie Canal siphon, and extends about 15 miles downstream to the Wyoming-Nebraska State line. Dry Creek is the only oignificant natural tributary along the study reach and is located about 5 miles downstream from the Fort Laramie Canal siphon. Along the study reach, land is irrigated by water diverted from Horse Creek; and water from the Fort Laramie Canal is added to Horse Creek.

\section{DATA COLLECTION}

Stream-discharge and water-quality measurements were made at four sites on Horse Creek and at one site on Dry Creek. Dry Creek was measured to define inflow to Horse Creek. The five sites (fig. 2-6, at end of report) were photographed on October 21,1985 and are identified as follows:

Site 1 - Horse Creek at siphon near Yoder, Wyoming

Site 2 - Dry Creek near Huntley, Wyoming

Site 3 - Horse Creek below Dry Creek near Huntley, Wyoming

Site 4 - Horse Creek above South Horse Creek lateral near

Huntley, Wyoming

Site 5 - Horse Creek near Lyman, Nebraska 


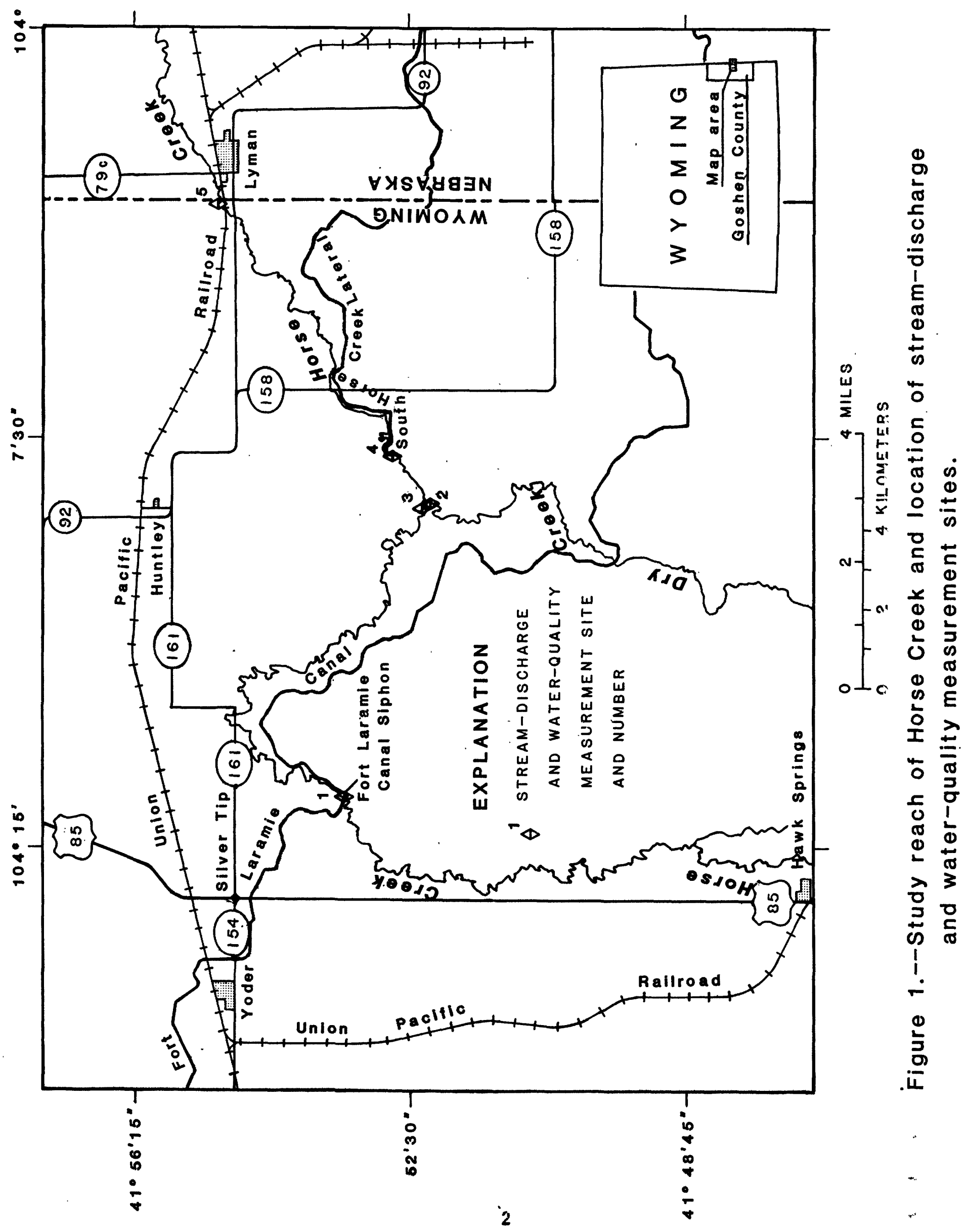


Measurements of stream discharge, specific conductance, $\mathrm{pH}$, and water temperature were made at the five sites during the reconnaissance of the area, May 9-10, 1985, and then were made twice-a-month from June 5 through November 21, 1985. Measurements are listed in tables 1-5 (at end of report) and are shown graphically in figures $7-11$.

Changes in stream discharge were calculated for three stream reaches between measurement sites on Horse Creek. The change in stream discharge given in table 6, at end of report (and shown graphically in figure-12), is the mathematical difference between streamflow measured at adjacent sites. Water that may have been diverted from, or added to, streamflow in Horse Creek botween sites was not measured or identified. No precipitation occurred during the measurements. The change between site 1 and site 3 was calculated by considering the discharge from Dry Creek (site 2) as inflow. Because all stream-discharge measurements were not made on the same day, no stream-discharge changes were computed from data collected on the initial reconnaissance of May 9-10, 1985.

Accuracy of discharge measurements can be affected by the condition of the measurement equipment, characteristics of the measurement section, changes in stage, and other factors (Rantz and others, 1982, p. 179). Stream-discharge measurements in this report are rated good, having an error of less than 5 percent.

Specific conductance and $\mathrm{pH}$ of composite water samples were measured at each site, and water temperature was measured at a single point in the discharge-measurement section. The composite water samples consisted of water collected at points along the cross section of the creek and at different depths at each point. These depth-integrated water samples were collected using the EWI (equal width increment) method, formerly known as ETR (equal transit rate) method (Guy and Norman, 1970, p. 32), and were composited in a churn sample splitter. Specific conductance is a measure of the ability of water to conduct an electrical current. It is expressed in microsiemens per centimeter at $25^{\circ}$ Celsius. Specific conductance is related to the type and concentration of ions in solution and can be used for approximating the dissolved-solids concentration of the water. Commonly, the concentration of dissolved solids (in milligrams per liter) is between 55 and 75 percent of the specific conductance; horever, this relation varies significantly according to the actual constituents in the water (Hem, 1985, p. 66-67). 
Guy, H. P., and Norman, V. W., 1970, Field methods for measurement of fluvisl sediment: U.S. Geological Survey Techniques of Water-Resources Investfgations, Book 3, Chapter C2, 59 p.

Hem, J. D., 1985, Study and interpretation of the chemical chafacteristics of natural water: U.S. Geological Survey Water-Supply Paper 2254, 264 p.

Rantz, S. E., and others, 1982, Measurement and computation of streamflor; Volume 1, Measurement of stage and discharge: U.S. Geological Survey Water-Supply Paper 2175, 284 p. 


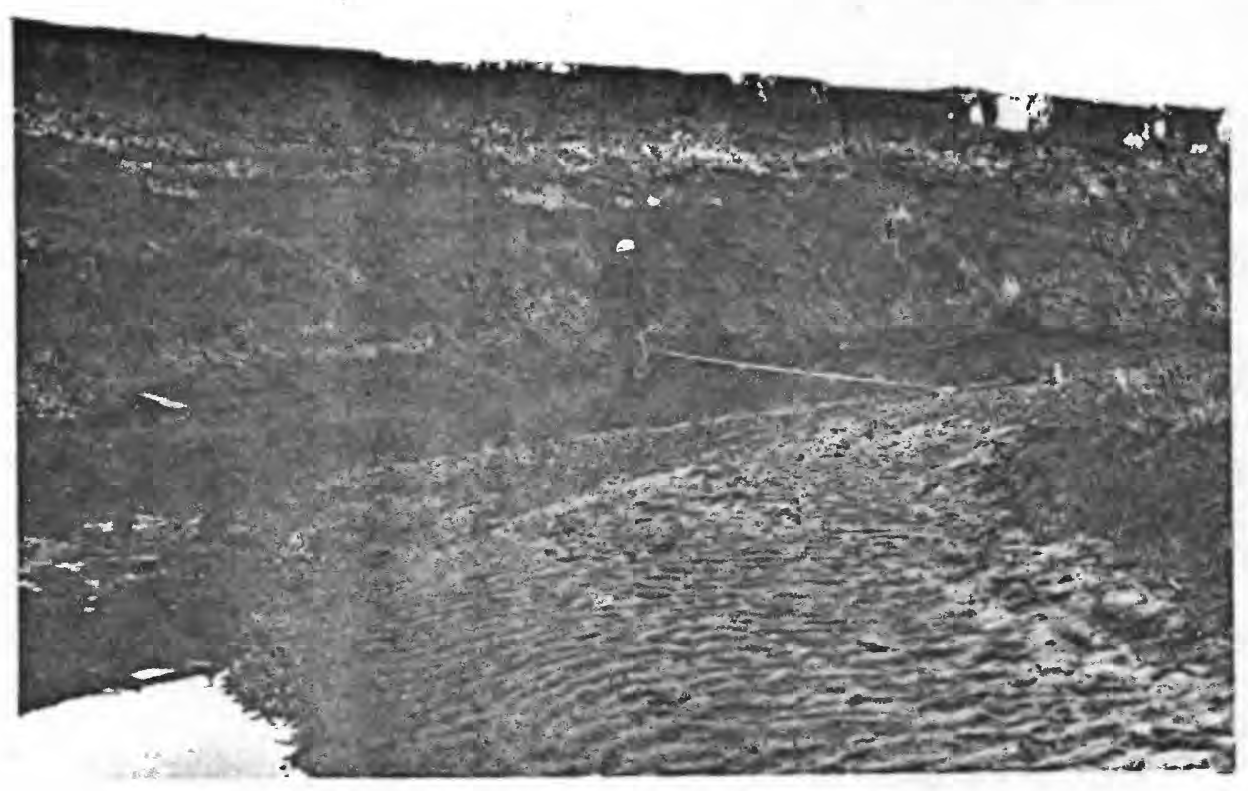

Figure 2.--Upstream view of Horse Creek at siphon near Yoder, Wyoming (site 1), October 21, 1985.

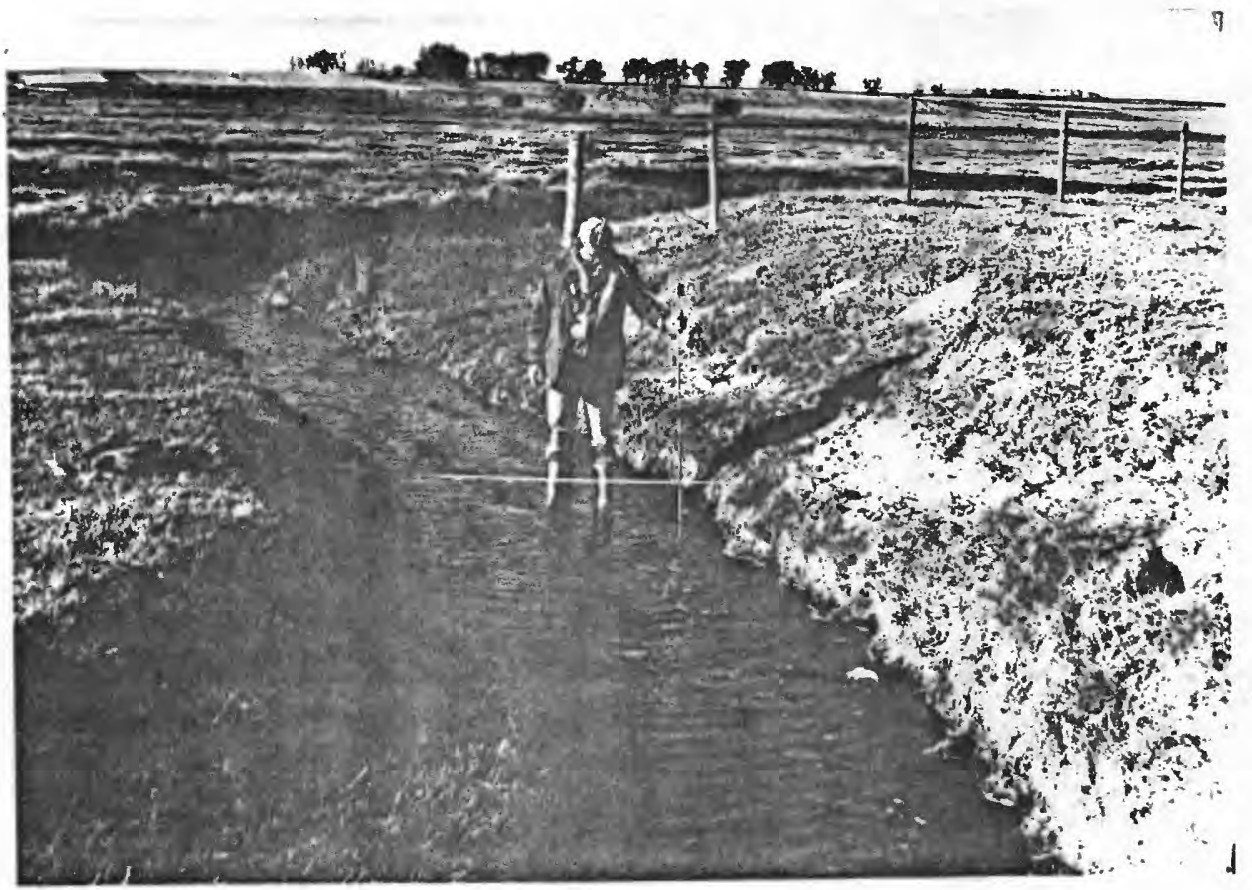

Flgure 3.--Downstream view of Dry Creek near Huntley, Wyoming (site 2), October 21, 1985. 


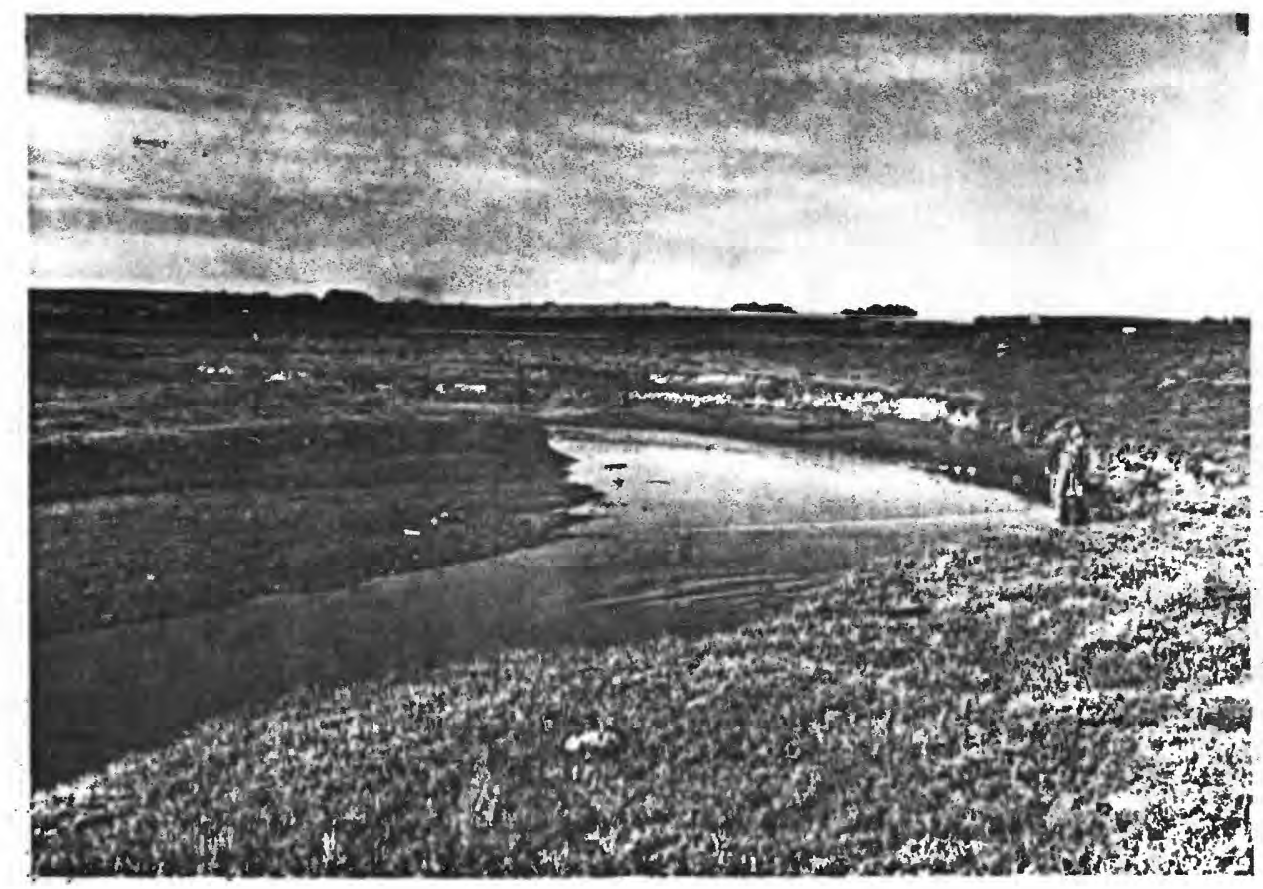

Figure 4.--Upstream view of Horse Creek below Dry Creek near Huntley, Wyoming (site 3), October 21, 1985.

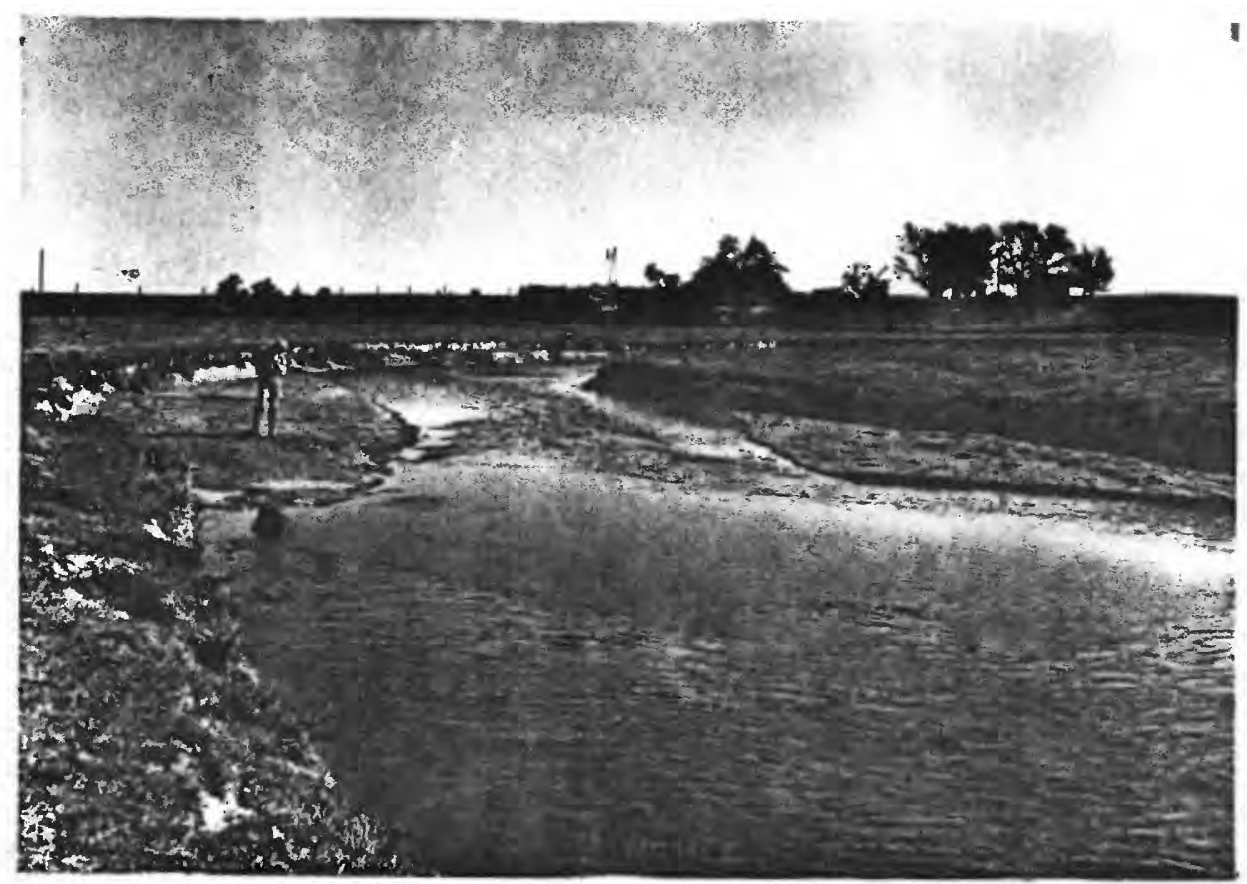

Figure 5.--Downstream view of Horse Creek above South Horse Creek lateral near Huntley, Wyoming (site 4), October $21,1985$. 


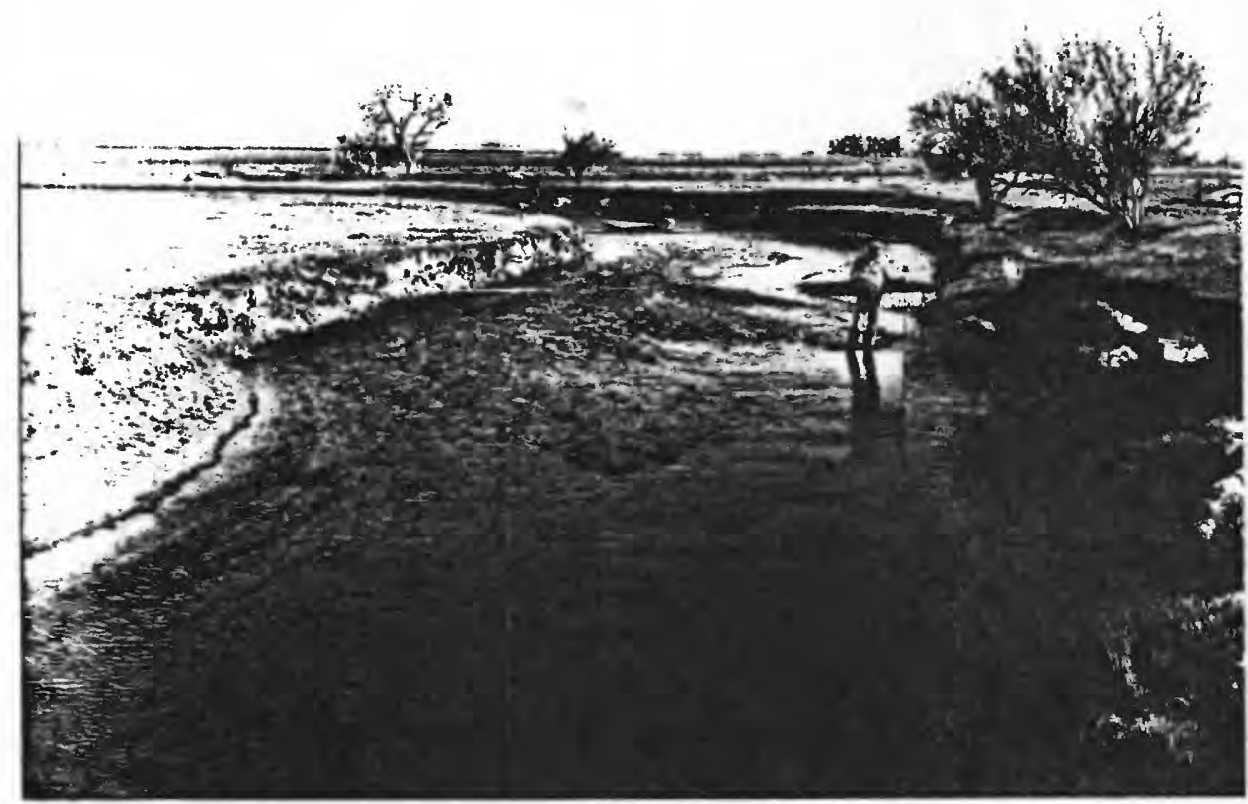

Figure 6.--Downstream view of Horse Creek near Lyman, Nebraska (site 5), October 21, 1985. 

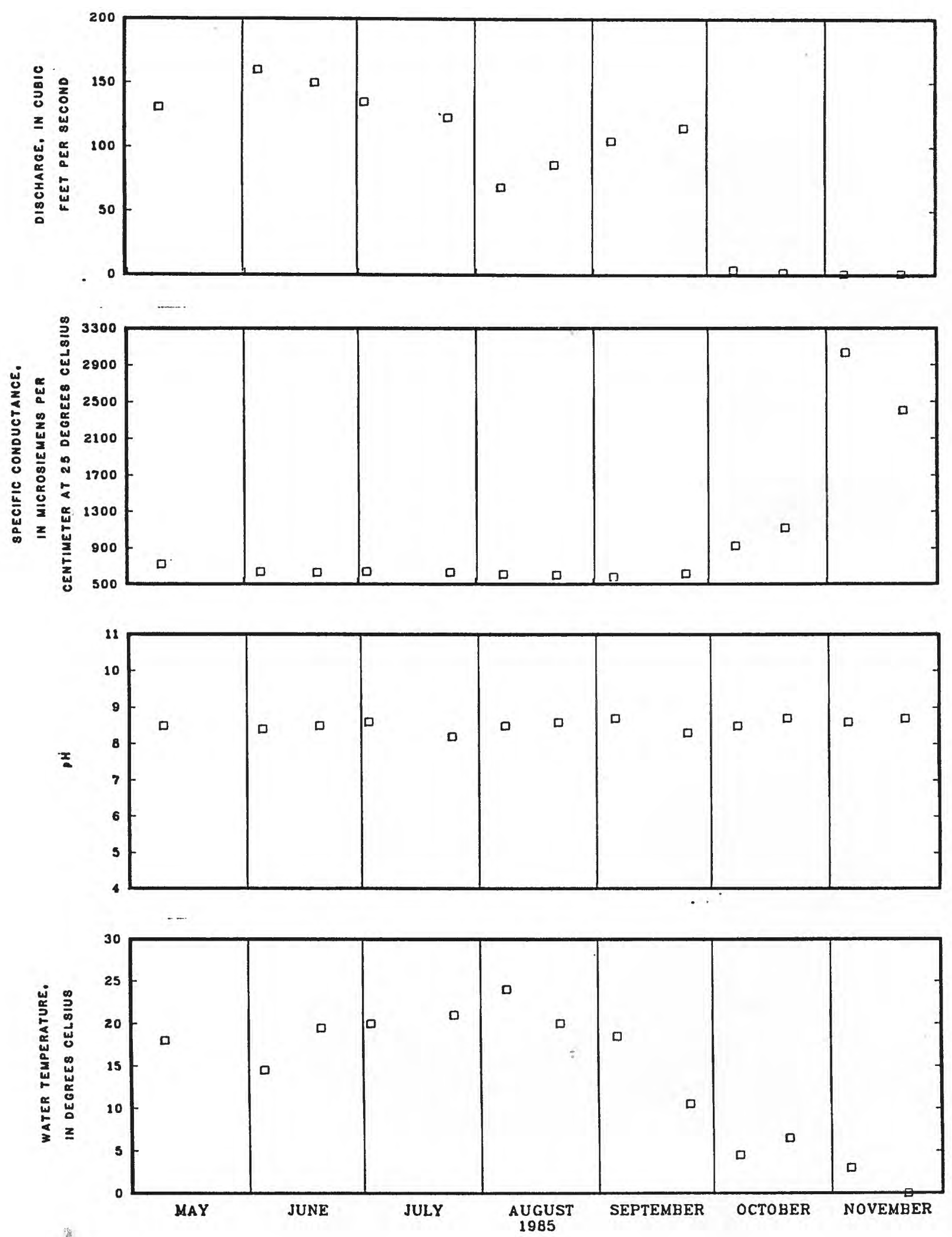

Figure 7.--Stream discharge, specific conductance, $\mathrm{pH}$, and water temperature at Horse Creek at siphon near Yoder, Wyoming (site 1). 

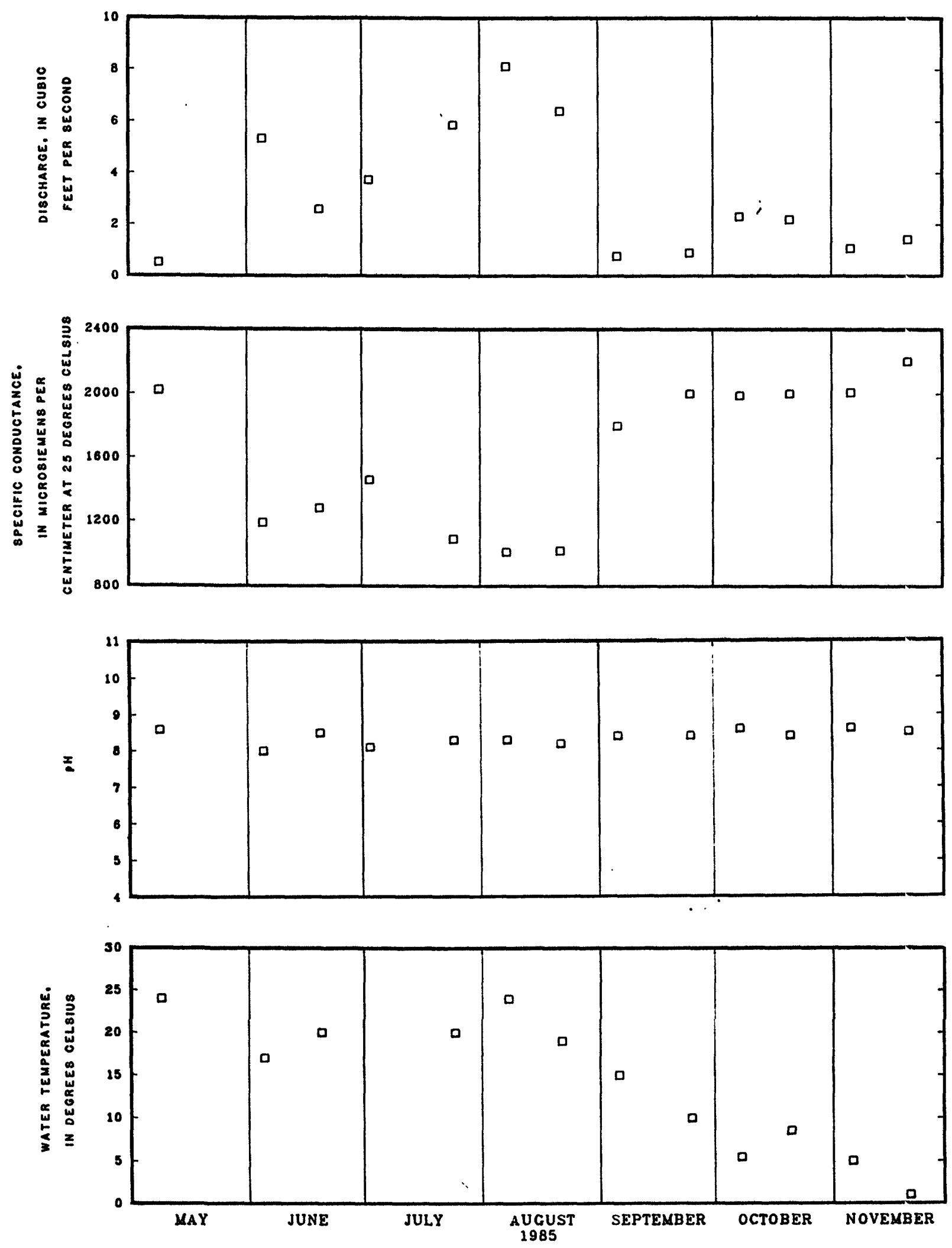

Figure 8.--Stream discharge, specific conductance, $\mathrm{pH}$, and water temperature at Dry Creek near Huntley, Wyoming (site 2). 

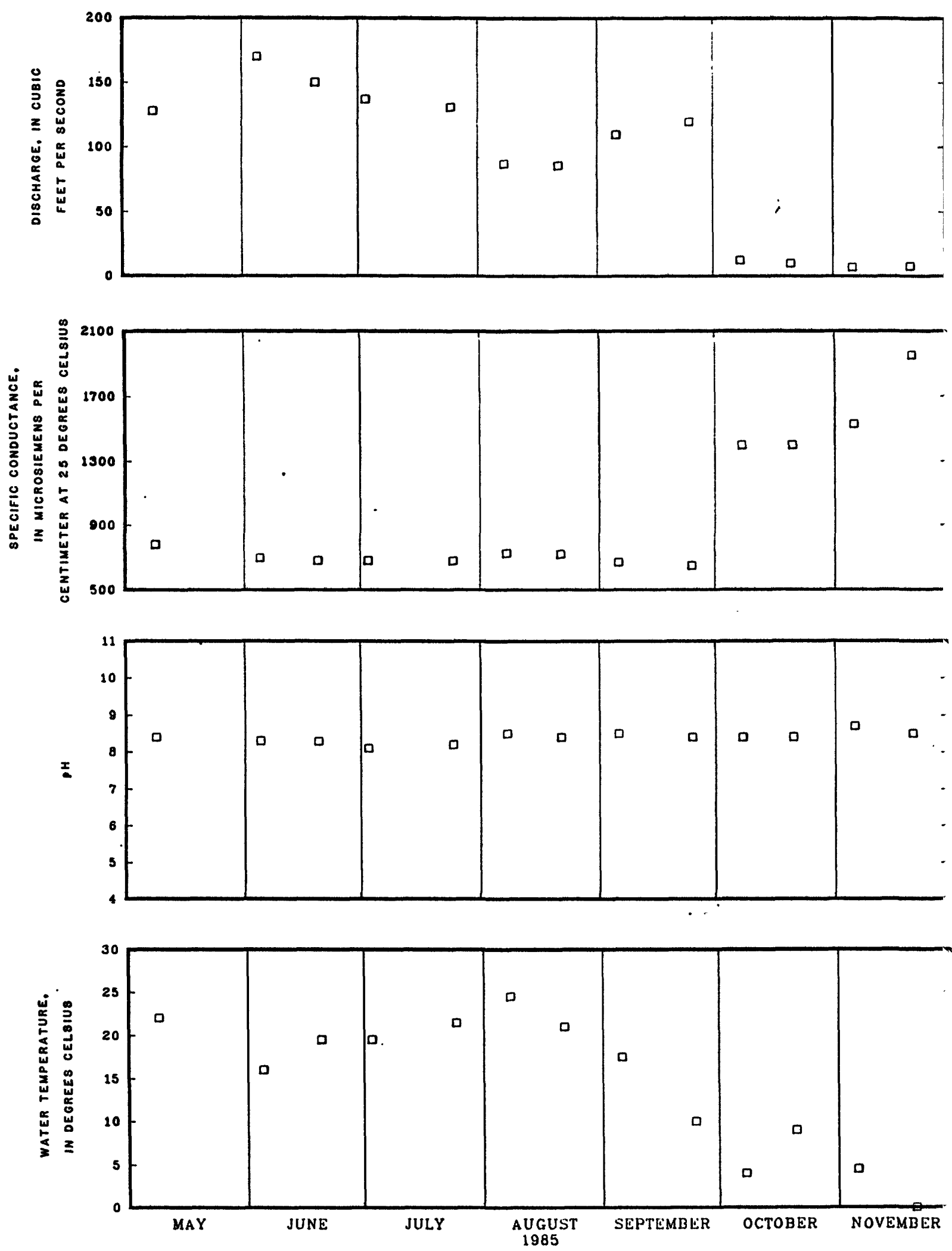

Figure 9.--Stream discharge, specific conductance, $\mathrm{pH}$, and water temperature at Horse Creek below Dry Creek near Huntley, Wyoming (site 3). 

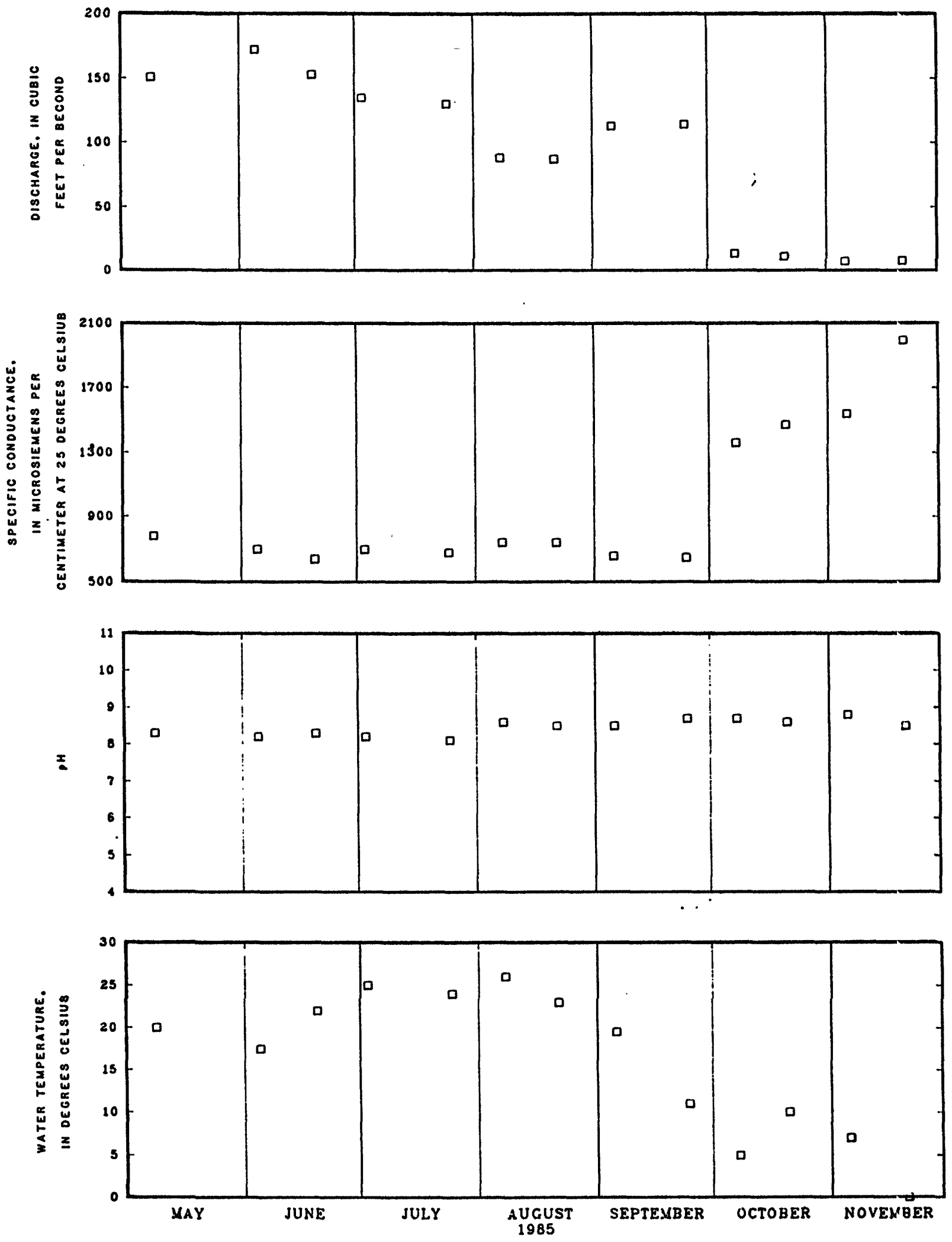

Figure 10.--Stream discharge, specific conductance, $\mathrm{pH}$, and water temperature at Horse Creek above South Horse Creek lateral near Huntley, Wyoming (site 4). 

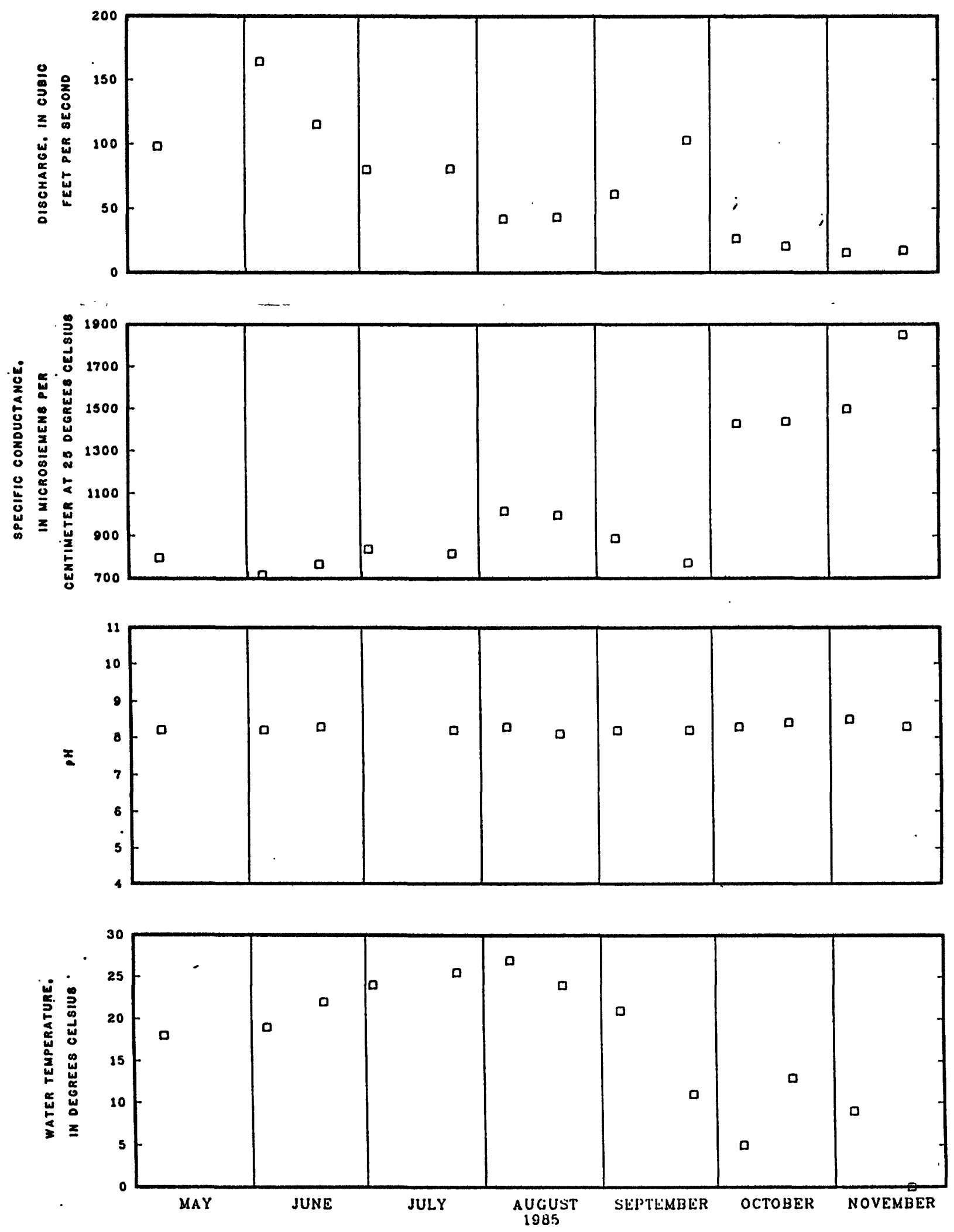

Figure 11.--Stream discharge, specific conductance, $\mathrm{pH}$, and water temperature at Horse Creek near Lyman, Nebraska (site 5). 


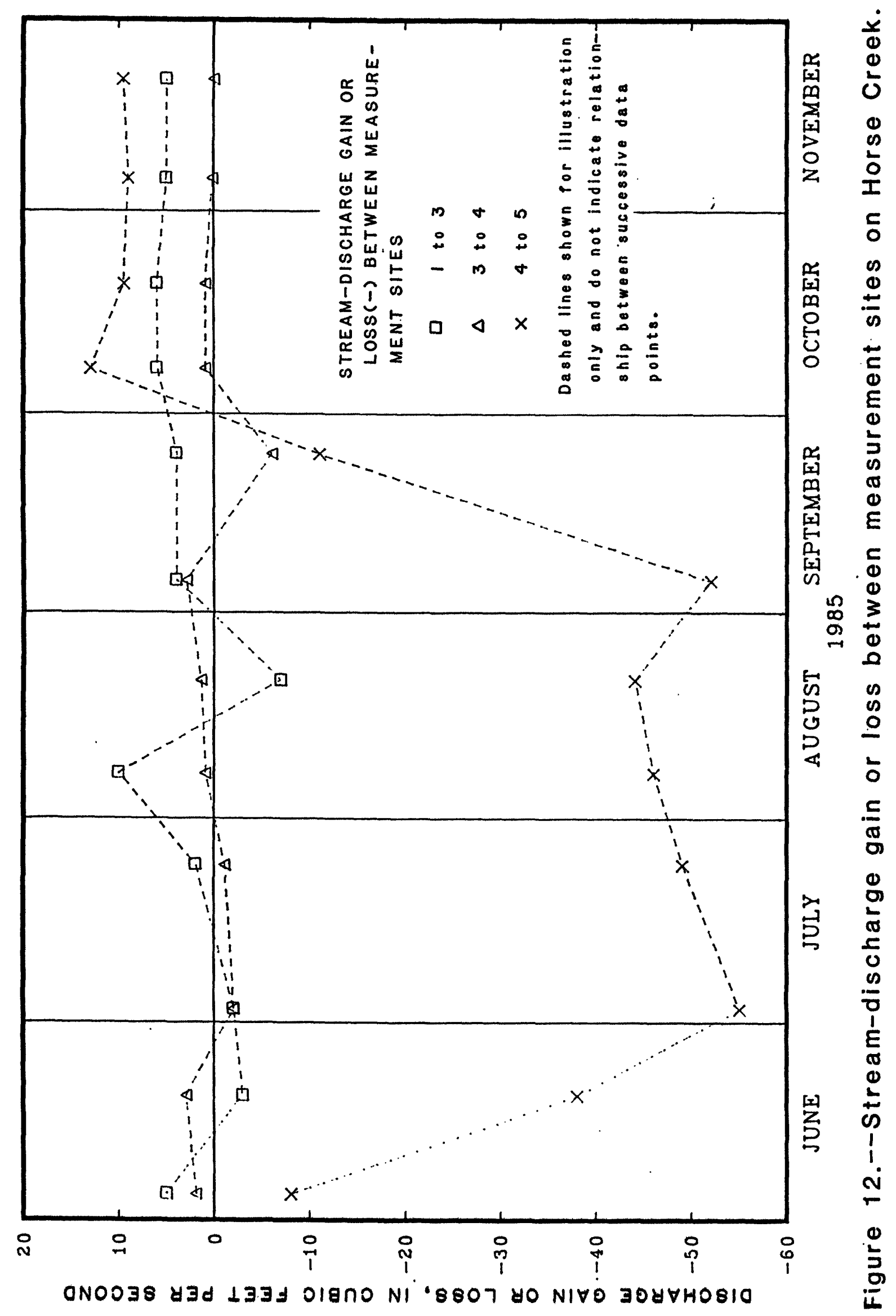


Table 1.--Stream-discharge and water-qual1ty measurements made during 1985 of Horse Creek at siphon near Yoder, Wyoming (site 1)

\begin{tabular}{llcccc}
\hline \multicolumn{1}{c}{ Date } & Time & $\begin{array}{c}\text { Discharge } \\
\text { (cubic feet } \\
\text { per second) }\end{array}$ & $\begin{array}{c}\text { Specific } \\
\text { conductance } \\
\text { (microsiemens per } \\
\text { centimeter at 25 } \\
\text { degrees Celsius) }\end{array}$ & $\begin{array}{c}\text { Water } \\
\text { temrer- } \\
\text { ature } \\
\text { (degrees } \\
\text { Celsius) }\end{array}$ \\
\hline May 10 & 0945 & 131 & 720 & 8.5 & 18.0 \\
June 5 & 0740 & 160 & 640 & 8.4 & 14.5 \\
June 20 & 0750 & 150 & 630 & 8.5 & 19.5 \\
July 3 & 0800 & 135 & 640 & 8.6 & 20.0 \\
July 25 & 0800 & 123 & 630 & 8.2 & 21.0 \\
August 8 & 1020 & 69.0 & 610 & 8.5 & 24.0 \\
August 22 & 0900 & 86.6 & 600 & 8.6 & 20.0 \\
September 6 & 0815 & 105 & 580 & 8.7 & 18.5 \\
September 25 & 0900 & 115 & 615 & 8.3 & 10.5 \\
October 8 & 0800 & 4.35 & 920 & 8.7 & 4.5 \\
October 21 & 0810 & 2.21 & 1120 & 8.6 & 3.0 \\
November 6 & 0810 & 0.91 & 3030 & 8.7 & 0.0 \\
November 21 & 0910 & 1.06 & 2400 & & \\
\hline
\end{tabular}

Table 2.--Stream-discharge and water-quality measurements made during 1985 of Dry Creek near Huntley, Wyoming (site 2)

\begin{tabular}{|c|c|c|c|c|c|}
\hline Date & Time & $\begin{array}{l}\text { Discharge } \\
\text { (cubic feet } \\
\text { per second) }\end{array}$ & $\begin{array}{c}\text { Specific } \\
\text { conductance } \\
\text { (microsiemens per } \\
\text { centimeter at } 25 \\
\text { degrees Celsius) }\end{array}$ & pH & $\begin{array}{l}\text { Water } \\
\text { temper- } \\
\text { ature } \\
\text { (degrees } \\
\text { Celsius) }\end{array}$ \\
\hline $\begin{array}{l}\text { May } 9 \\
\text { June } 5 \\
\text { June } 20 \\
\text { July } 3 \\
\text { July } 25 \\
\text { August } 8 \\
\text { August } 22 \\
\text { September } 6 \\
\text { September } 25 \\
\text { October } 8 \\
\text { October } 21 \\
\text { November } 6 \\
\text { November } 21\end{array}$ & $\begin{array}{l}1740 \\
0910 \\
1020 \\
1100 \\
1100 \\
1330 \\
1200 \\
1045 \\
1145 \\
1100 \\
0920 \\
1030 \\
1120\end{array}$ & $\begin{array}{l}0.52 \\
5.32 \\
2.58 \\
3.73 \\
5.86 \\
8.11 \\
6.41 \\
.78 \\
.90 \\
2.31 \\
2.19 \\
1.08 \\
1.42\end{array}$ & $\begin{array}{l}2020 \\
1190 \\
1280 \\
1460 \\
1090 \\
1010 \\
1020 \\
1800 \\
2000 \\
1990 \\
2000 \\
2010 \\
2200\end{array}$ & $\begin{array}{l}8.6 \\
8.0 \\
8.5 \\
8.1 \\
8.3 \\
8.3 \\
8.2 \\
8.4 \\
8.4 \\
8.6 \\
8.4 \\
8.6 \\
8.5\end{array}$ & $\begin{array}{l}24.0 \\
17.0 \\
20.0 \\
-- \\
27.0 \\
24.0 \\
19.0 \\
15.0 \\
10.0 \\
5.5 \\
8.5 \\
5.0 \\
1.0\end{array}$ \\
\hline
\end{tabular}


Table 3.--Stream-discharge and water-quality measurements made during 1985 of Horse Creek below Dry Creek near Huntley, Wyoming (site 3)

\begin{tabular}{llccrr}
\hline \multicolumn{1}{c}{ Date } & Time & $\begin{array}{c}\text { Sischarge } \\
\text { (cubic feet } \\
\text { per second) }\end{array}$ & $\begin{array}{c}\text { Specific } \\
\text { conductance } \\
\text { (microsiemens per } \\
\text { centimeter at 25 } \\
\text { degrees Celsius) }\end{array}$ & pH & $\begin{array}{c}\text { Water } \\
\text { temper- } \\
\text { ature } \\
\text { (degrees } \\
\text { Celsius) }\end{array}$ \\
\hline May 9 & 1640 & 128 & 780 & 8.4 & 22.0 \\
June 5 & 0955 & 170 & 700 & 8.3 & 16.0 \\
June 20 & 1030 & 150 & 680 & 8.3 & 19.5 \\
July 3 & 1000 & 137 & 680 & 8.1 & 19.5 \\
July 25 & 1115 & 131 & 680 & 8.2 & 21.5 \\
August 8 & 1310 & 87.0 & 725 & 8.5 & 24.5 \\
August 22 & 1145 & 85.7 & 720 & 8.4 & 21.0 \\
September 6 & 1030 & 110 & 670 & 8.5 & 17.5 \\
September 25 & 1200 & 120 & 650 & 8.4 & 10.0 \\
October 8 & 1045 & 12.4 & 1400 & 8.4 & 4.0 \\
October 21 & 0930 & 10.0 & 1400 & 8.4 & 9.0 \\
November 6 & 1010 & 6.78 & 1530 & 8.7 & 4.5 \\
November 21 & 1130 & 7.44 & 1950 & 8.5 & 0.0 \\
\hline
\end{tabular}

Table 4.--Stream-discharge and water-quality measurements made during 1985 of Horse Creek above South Horse Creek lateral near Huntley, Wyoming (site 4)

\begin{tabular}{|c|c|c|c|c|c|}
\hline Date & TIme & $\begin{array}{l}\text { Discharge } \\
\text { (cubic feet } \\
\text { per second) }\end{array}$ & $\begin{array}{c}\text { Spectfic } \\
\text { conductance } \\
\text { (microsiemens per } \\
\text { centimeter at } 25 \\
\text { degrees Celsius) }\end{array}$ & $\mathbf{p H}$ & $\begin{array}{l}\text { Water } \\
\text { temper- } \\
\text { ature } \\
\text { (degrees } \\
\text { Celsius) }\end{array}$ \\
\hline $\begin{array}{l}\text { May } 9 \\
\text { June } 5 \\
\text { June } 20 \\
\text { July } 3 \\
\text { July } 25 \\
\text { August } 8 \\
\text { August } 22 \\
\text { September } 6 \\
\text { September } 25 \\
\text { October } 8 \\
\text { October } 21 \\
\text { November } 6 \\
\text { November } 21\end{array}$ & $\begin{array}{l}1440 \\
1115 \\
1235 \\
1200 \\
1310 \\
1500 \\
1345 \\
1230 \\
1350 \\
1215 \\
1035 \\
1210 \\
1300\end{array}$ & $\begin{array}{l}151 \\
172 \\
153 \\
135 \\
130 \\
88.2 \\
87.2 \\
113 \\
114 \\
13.3 \\
11.0 \\
7.12 \\
7.55\end{array}$ & $\begin{array}{l}780 \\
700 \\
640 \\
700 \\
680 \\
740 \\
740 \\
660 \\
650 \\
1360 \\
1470 \\
1540 \\
1990\end{array}$ & $\begin{array}{l}8.3 \\
8.2 \\
8.3 \\
8.2 \\
8.1 \\
8.6 \\
8.5 \\
8.5 \\
8.7 \\
8.7 \\
8.6 \\
8.8 \\
8.5\end{array}$ & $\begin{array}{r}20.0 \\
17.5 \\
22.0 \\
25.0 \\
24.0 \\
26.0 \\
23.0 \\
19.5 \\
11.0 \\
5.0 \\
10.0 \\
7.0 \\
0.0\end{array}$ \\
\hline
\end{tabular}


Table 5.--Stream-discharge and water-quality measurements made during 1985 of Horse Creek near Lyman, Nebraska (site 5)

\begin{tabular}{llccrc}
\hline \multicolumn{1}{c}{ Date } & Time & $\begin{array}{c}\text { Sischarge } \\
\text { (cubic feet } \\
\text { per second) }\end{array}$ & $\begin{array}{c}\text { Specific } \\
\text { conductance } \\
\text { (microsiemens per } \\
\text { centimeter at 25 } \\
\text { degrees Celsius) }\end{array}$ & pH & $\begin{array}{c}\text { Water } \\
\text { temper- } \\
\text { ature } \\
\text { (degrees } \\
\text { Celsius) }\end{array}$ \\
\hline May 9 & 1110 & 98.0 & 800 & 8.2 & 18.0 \\
June 5 & 1300 & 164 & 720 & 8.2 & 19.0 \\
June 20 & 1420 & 115 & 770 & 8.3 & 22.0 \\
July 3 & 1400 & 80.0 & 840 & - & 24.0 \\
July 25 & 1515 & 80.9 & 820 & 8.2 & 25.5 \\
August 8 & 1645 & 42.0 & 1020 & 8.3 & 27.0 \\
August 22 & 1530 & 43.2 & 1000 & 8.1 & 24.0 \\
September 6 & 1415 & 61.1 & 890 & 8.2 & 21.0 \\
September 25 & 1545 & 103 & 775 & 8.2 & 11.0 \\
October 8 & 1350 & 26.4 & 1430 & 8.3 & 5.0 \\
October 21 & 1240 & 20.5 & 1440 & 8.5 & 13.0 \\
November 6 & 1340 & 15.7 & 1500 & 8.3 & 9.0 \\
November 21 & 1445 & 17.2 & 1850 & 0.0 \\
\hline
\end{tabular}

Table 6.--Stream-discharge changes for three stream reaches located between measurement sites on Horse Creek

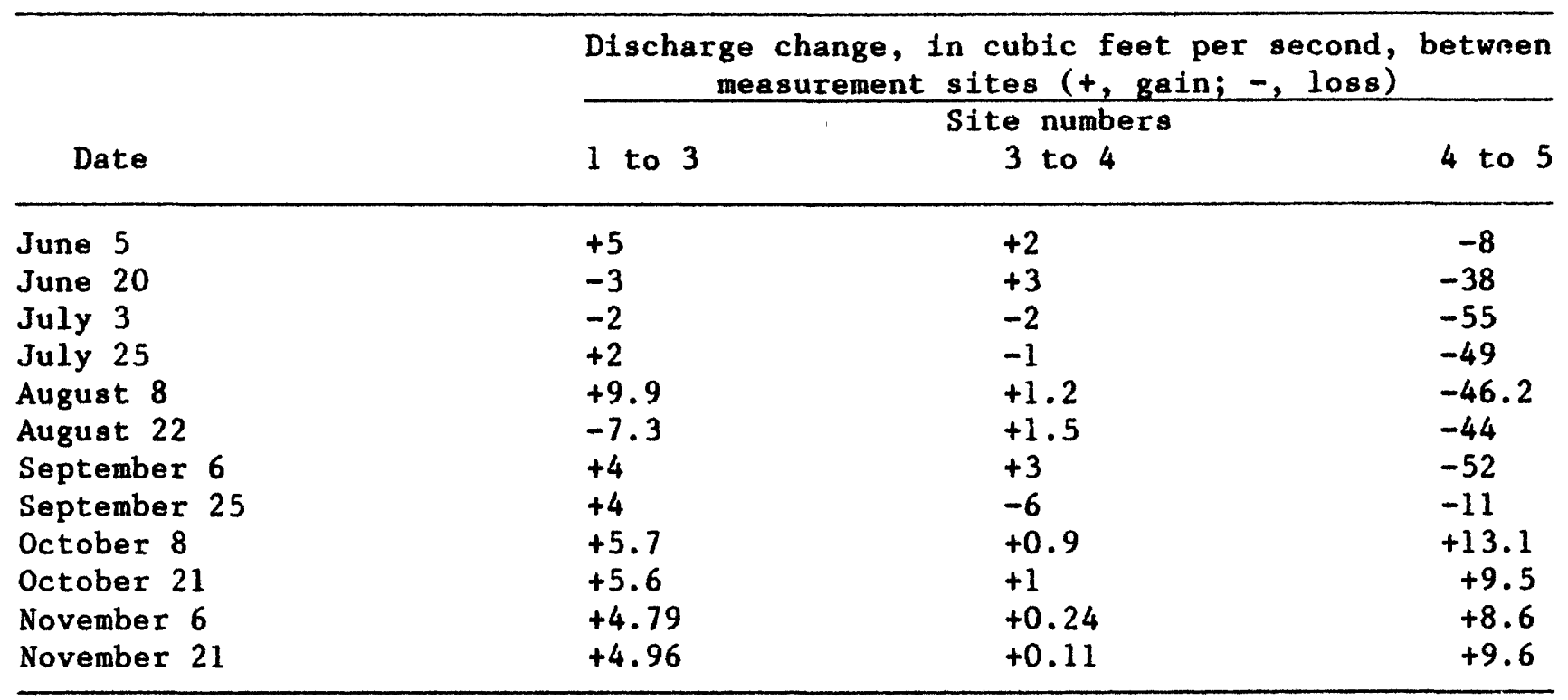

